Article

\title{
Coal Mining Waste as a Future Eco-Efficient Supplementary Cementing Material: Scientific Aspects
}

\author{
Moisés Frías ${ }^{1, *}$, Rosario García ${ }^{2}$, Raquel Vigil de la Villa ${ }^{2}$ and Sagrario Martínez-Ramírez ${ }^{3}$ \\ 1 Eduardo Torroja Institute for Construction Sciences (IETcc-CSIC), Madrid 28033, Spain \\ 2 CSIC-UAM Associated Unit, Department of Geology and Geochemistry, Autonomous University of Madrid, \\ Madrid 28049, Spain; rosario.garcia@uam.es (R.G.); raquel.vigil@uam.es (R.V.d.l.V.) \\ 3 Institute for the Structure of Matter (IEM-CSIC), Madrid 28006, Spain; sagrario@iem.cfmac.csic.es \\ * Correspondence: mfrias@ietcc.csic.es; Tel.: +34-91-302-0440
}

Academic Editors: Michele Rosano, Katerina Adam and Maria Menegaki Received: 20 May 2016; Accepted: 5 July 2016; Published: 16 July 2016

\begin{abstract}
The stockpiling of tailings around coal mines poses a major environmental problem. Nonetheless, this clay mineral (kaolinite)-based waste can be reused as a supplementary cementitious material (recycled metakaolinite) in the manufacture of future eco-efficient cements. This paper explores the most significant scientific questions posed in connection with the conversion of this waste into pozzolans, such as the variation in product mineralogy depending on the sintering temperature and its effect on reaction kinetics in the pozzolan/Ca(OH $)_{2}$ system over a period of 365 days. The findings show that the optimal sintering temperature is $600{ }^{\circ} \mathrm{C}$, such that the cementitious properties of the activated product are determined solely by the conversion of kaolinite into metakaolinite and are unaffected by the other clay minerals (micas). The presence of $20 \%$ activated coal waste favors the formation of larger amounts of aluminous phases such as $\mathrm{C}_{4} \mathrm{AH}_{13}$ and $\mathrm{C}_{4} \mathrm{AcH}_{12}$ than in the reference paste and enhances $\mathrm{C}-\mathrm{S}-\mathrm{H}$ gel polymerization.
\end{abstract}

Keywords: coal mining waste; mineralogy; blended cements; hydrated phases

\section{Introduction}

Today's society is undergoing a change from a linear (produce-use-discard) to a recycling-based circular economic model that pursues two ends: the generation of less waste and its reuse as raw materials in industrial processes. This sustainable approach is one of the mainstays of Europe's 2020 strategy [1].

Cement manufacturing is a benchmark in this regard, in light of its use decades-old use of industrial by-products and waste in different stages of production: as alternative fuels (worn tires), raw materials (waste water treatment sludge) or supplementary cementitious materials (SCMs) to produce eco-efficient cements [2-4]. Metakaolinite, a material well known for its high pozzolanicity that can be obtained by thermally activating natural kaolinite, is one of the standardized SCMs [5-11]. Products with a high metakaolinite content can also be obtained by activating high-kaolinite industrial waste, a more eco-friendly approach compliant with the fundamental premises of the circular economy [12-14].

The stockpiling of kaolinite-based coal mining waste $(\mathrm{CW})$ has been posing severe environmental problems for decades [15-17]. These tailings are one of the primary sources of pollution in China [18], where around 4.5 billion tons have accumulated in over 1700 dumps, together occupying an area of $150 \mathrm{~km}^{2}$. In light of its kaolinitic nature, if recycled, this carbon waste may be an alternative source of MK [19-21]. Prior research conducted by Frías et al. [22,23], García et al. [24] and Vegas et al. [25] has 
shown that this inert waste can be converted by thermal activation into a high added value pozzolan (activated coal waste, ACW) apt for use in the manufacture of innovative eco-efficient cements. The need has thus arisen to determine the short- and long-term behavior of these pozzolanic materials in blended cements.

This study expands on the existing scientific knowledge of both preliminary thermal activation and the subsequent hydration of these materials when blended with cement. A number of instrumental techniques (XRD, SEM-EDX, TG/DTA, micro-Raman and NMR) are deployed to analyze the phases initially present in the thermally activated MK and in 365 days hydrated blends containing $80 \%$ cement. The findings are compared to the results for a reference Ordinary Portland Cement (OPC) paste to determine the effect of the pozzolanic reaction between the ACW and the portlandite in the blended cement system.

\section{Experimental Section}

\subsection{Materials}

Raw coal mining waste (CW) was collected in the vicinity of an open-pit mine owned by Sociedad Anónima Hullera Vasco-Leonesa and located in the Spanish province of Leon. The waste was crushed, sieved under 90 microns and thermally activated at temperatures ranging from $600{ }^{\circ} \mathrm{C}$ to $900{ }^{\circ} \mathrm{C}$ for $2 \mathrm{~h}$ to produce ACW. Laser granulometry results showed that $10 \%, 50 \%$ and $90 \%$ of the ACW particles are less than 1.7, 8.11 and 32.63 microns, respectively.

The cement used was a commercial ordinary portland cement classified as CEM I $52.5 \mathrm{~N}$ [2]. The potential composition of the Portland clinker, computed as stipulated in the existing Spanish legislation [26], is given in Table 1. The blended cements contained $20 \% \mathrm{ACW}$, the maximum replacement ratio allowed for the manufacture of type II/A cements $(6 \%-20 \%)$. After removal from the molds, the $1 \mathrm{~cm} \times 1 \mathrm{~cm} \times 6 \mathrm{~cm}$ prismatic specimens were cured in water at $20^{\circ} \mathrm{C}$ until tested at 1 , 28 or 365 days.

Table 1. Potential composition of clinker.

\begin{tabular}{ccccc}
\hline $\mathbf{( \% )}$ & $\mathrm{C}_{3} \mathrm{~S}$ & $\mathrm{C}_{2} \mathrm{~S}$ & $\mathrm{C}_{3} \mathrm{~A}$ & $\mathrm{C}_{4} \mathrm{AF}$ \\
\hline $\mathrm{OPC}$ & 43.61 & 27.71 & 9.29 & 9.70 \\
\hline
\end{tabular}

\subsection{Analytical Methods}

The accelerated chemical method $\left(40^{\circ} \mathrm{C}\right)$ was applied to assess the pozzolanicity of the carbon waste activated for $2 \mathrm{~h}$ at $600{ }^{\circ} \mathrm{C}$ in an electrical muffle furnace. Further to that method, $1 \mathrm{~g}$ of pozzolan was immersed in $75 \mathrm{~mL}$ of saturated lime solution for a given reaction time. The solution was subsequently filtered and the $\mathrm{CaO}$ concentration was calculated in both the problem and control solutions. The sole difference between this method and the standardized pozzolanicity test for pozzolanic cements lies in the material, which was a pozzolan rather than a cement.

\subsection{Instrumental Techniques}

The mineralogical composition of the bulk samples was determined by X-ray powder diffraction (XRD) and the $<2 \mu \mathrm{m}$ fraction by the oriented film method, both on a Siemens D-5000 (Munich, Germany) X-ray diffractometer fitted with a $\mathrm{Cu}$ anode. Semi-quantitative mineralogical composition was calculated with the powder reflection method. The areas under the reflections for each mineral were found with Gaussian fitting, in which conventional software was applied to subtract the baseline intensity. The relative error for this method was calculated at $10 \%$.

Sample morphology and microanalysis were conducted on an FEI Inspect (Hillsboro, OR, USA) scanning electron microscope equipped with a tungsten $(\mathrm{W})$ source DX4i dispersive X-ray analyzer and an $\mathrm{Si} / \mathrm{Li}$ detector. The chemical composition was determined as the mean of ten scans per sample, 
shown along with the standard deviation. The chemical formulas for the minerals were determined with EDS semi-quantitative analysis and the results expressed in oxides (wt.\%).

TG/DTA trials were run on a Stanton Equipment Inc. STA 781 thermogravimetric analyzer. Powder samples weighing $30 \mathrm{mg}$ to $35 \mathrm{mg}$ were heated at a rate of $10^{\circ} \mathrm{C} / \mathrm{min}$ in an $\mathrm{N}_{2}$ atmosphere.

Dispersive Raman spectra were recorded at $532 \mathrm{~nm}$ (Nd:YAG) on a Renishaw InVia system fitted with a Leica confocal Raman microscope and an electrically cooled CCD camera. Frequency was calibrated to silicon $\left(520 \mathrm{~cm}^{-1}\right)$ and the spectral resolution was set at $4 \mathrm{~cm}^{-1}$.

The Bruker AVANCE-400 (9.4 T) spectrometer used for ${ }^{29} \mathrm{Si}$ NMR analysis operated at a ${ }^{29} \mathrm{Si}$ frequency of $79.4 \mathrm{MHz}$. Kaolin $(\mathrm{d}=-91.5 \mathrm{ppm})$ referenced to TMS $(\mathrm{d}=0 \mathrm{ppm})$ was used as the external standard for chemical shift. The delay time was $60 \mathrm{~s}$ and the spinning speed $4 \mathrm{kHz}$.

\section{Results and Discussion}

\subsection{Comparison of Mineralogy after Activation at $500^{\circ} \mathrm{C}$ to $900^{\circ} \mathrm{C}$}

According to the XRD findings, the CW sample contained phyllosilicates (micas and kaolinite), quartz, calcite, dolomite and feldspars (Figure 1). Pozzolanic activity was induced by the phyllosilicates, for thermal activation in air at $600{ }^{\circ} \mathrm{C}$ to $900{ }^{\circ} \mathrm{C}$ is known to prompt dehydroxylation in many clay minerals $[27,28]$, with the concomitant total or partial breakdown of their crystalline lattice structure and the formation of a highly reactive transition phase.

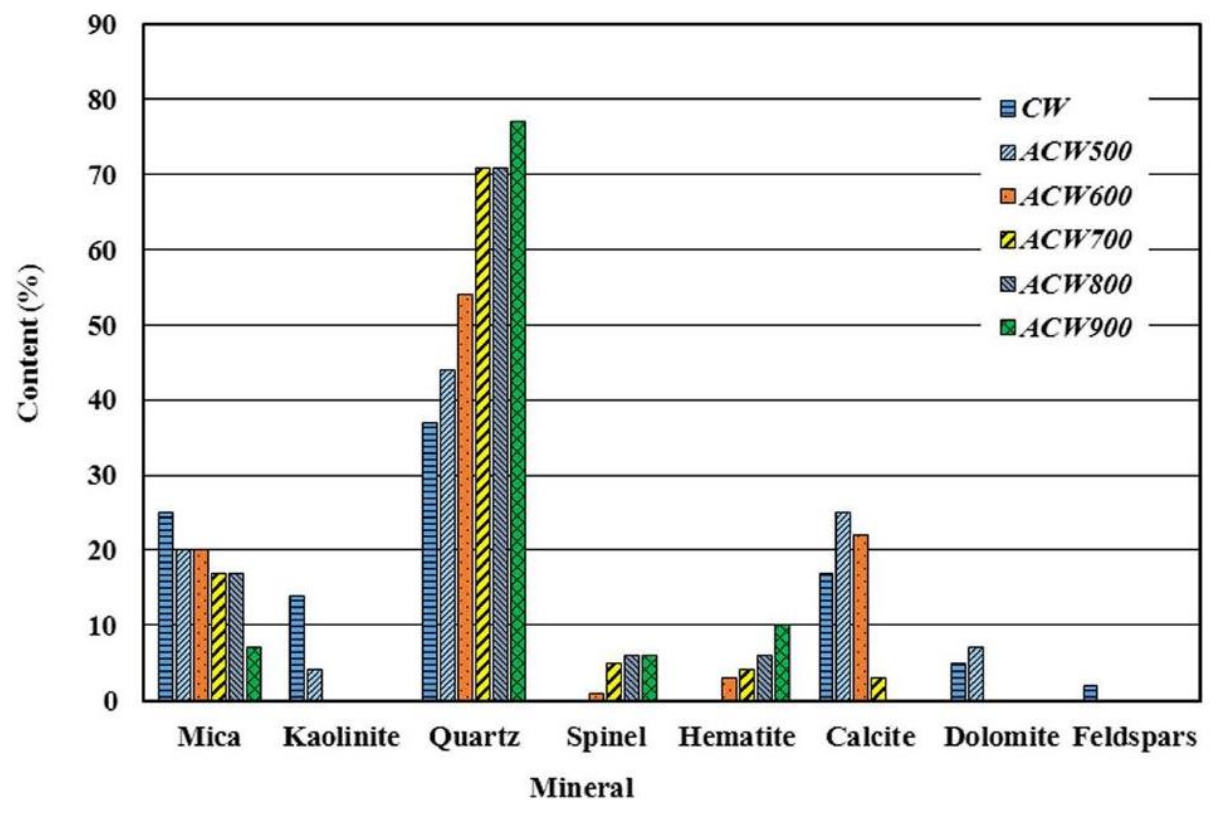

Figure 1. X-ray powder diffraction (XRD)-determined mineralogical composition (\%) for the starting (CW) and thermally treated (ACW 500/900) coal waste.

Clay is most reactive when the activation-induced loss of hydroxyl ions leads to structural collapse and disarrangement. The sintering temperature required to convert inert kaolinite into activated metakaolinite (MK) usually ranges from $600{ }^{\circ} \mathrm{C}$ to $800^{\circ} \mathrm{C}$. Mica, in contrast, must be heated to over $930^{\circ} \mathrm{C}$ to be activated and even then yields weak pozzolans.

The waste was heated at $500^{\circ} \mathrm{C}, 600^{\circ} \mathrm{C}, 700^{\circ} \mathrm{C}, 800^{\circ} \mathrm{C}$ and $900^{\circ} \mathrm{C}$ to determine the optimal temperature for phyllosilicate dehydroxylation and new phase formation. The XRD results showed that full kaolinite dehydroxylation took place at $600{ }^{\circ} \mathrm{C}$, with spinel-like phase neoformation occurring at $900{ }^{\circ} \mathrm{C}$ (Figure 1). The metakaolinite clusters visible in the SEM micrographs of ACW-600 were spongy and had blurred edges, whereas in the ACW-900 product the MK clusters were compact and had very sharply defined edges (Figure 2). 

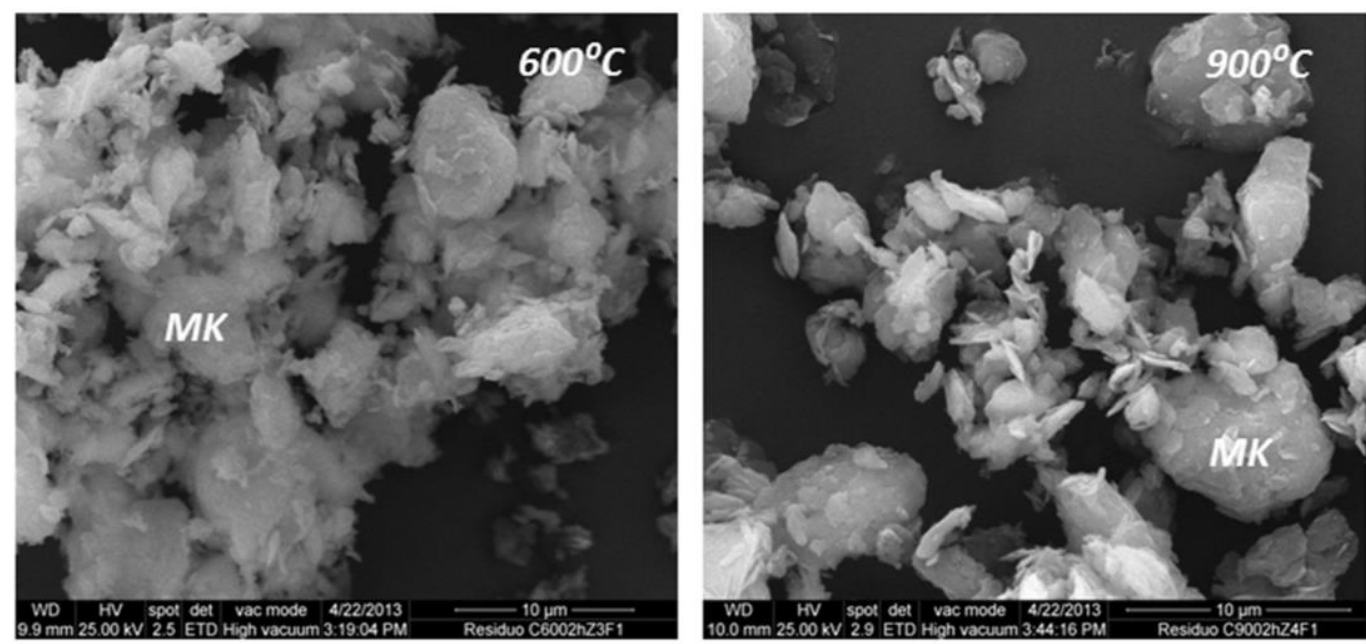

Figure 2. Micrographs of ACW produced by sintering $\mathrm{CW}$ at $600^{\circ} \mathrm{C}$ (left) and $900{ }^{\circ} \mathrm{C}$ (right).

Consequently, $600{ }^{\circ} \mathrm{C}$ was the temperature required to convert the kaolinite in coal waste into metakaolinite.

\subsection{Pozzolanic Activity}

The amount of lime fixed by the activated waste over time (found with the accelerated chemical method described in the experimental section) was expressed as the ratio between the $\mathrm{CaO}$ content (in $\mathrm{mmol} / \mathrm{L}$ ) in the problem solution and the content in the control solution to obtain the pozzolanic index (PI) at each test age. According to the data in Table 2, waste ACW-600 exhibited high pozzolanicity, because $80 \%$ of the lime had been consumed in the first 28 days. The reaction rate declined after that age, with a PI of only $89 \%$ after 365 days. The behavior of ACW-600 was comparable (except in the first $24 \mathrm{~h}$ ) to that of other types of industrial waste such as silica fume (SF) and bamboo leaf ash (BLA), regarded in the literature to be highly reactive pozzolans [29-31].

Table 2. Pozzolanic index (\%) for ACW-600, bamboo leaf ash (BLA) and silica fume (SF) by hydration time.

\begin{tabular}{cccc}
\hline PI (\%) & ACW-600 & BLA & SF \\
\hline 1 day & 44.6 & 81.9 & 83.1 \\
28 days & 80.3 & 90.9 & 88.2 \\
90 days & 86.7 & 91.4 & 88.2 \\
365 days & 89.9 & 92.1 & 90.1 \\
\hline
\end{tabular}

\subsection{Hydrated Phase Behavior}

\subsubsection{XRD Analyses}

$\mathrm{XRD}$ analysis detected portlandite, ettringite, tetracalcium aluminate hydrate $\left(\mathrm{C}_{4} \mathrm{AH}_{13}\right)$ and tetracalcium aluminate carbonate hydrate $\left(\mathrm{C}_{4} \mathrm{AcH}_{12}\right)$ in both the OPC and the $20 \%$ ACW blended cement (Figures 3 and 4, respectively). The proportions of each crystalline hydrated phase varied with hydration time and the presence or absence of the ACW.

Portlandite was the predominant hydrated phase in OPC at all test ages, followed in the first 28 days by ettringite. Tetracalcium aluminate carbonate hydrate $\left(\mathrm{C}_{4} \mathrm{AcH}_{12}\right)$ formation was clearly visible after the first 28 days and the content of this phase remained flat throughout the period studied. Tetracalcium aluminate hydrate $\left(\mathrm{C}_{4} \mathrm{AH}_{13}\right)$ was detected at 365 days. Portlandite declined substantially after 365 days and ettringite only slightly, while calcite grew. 


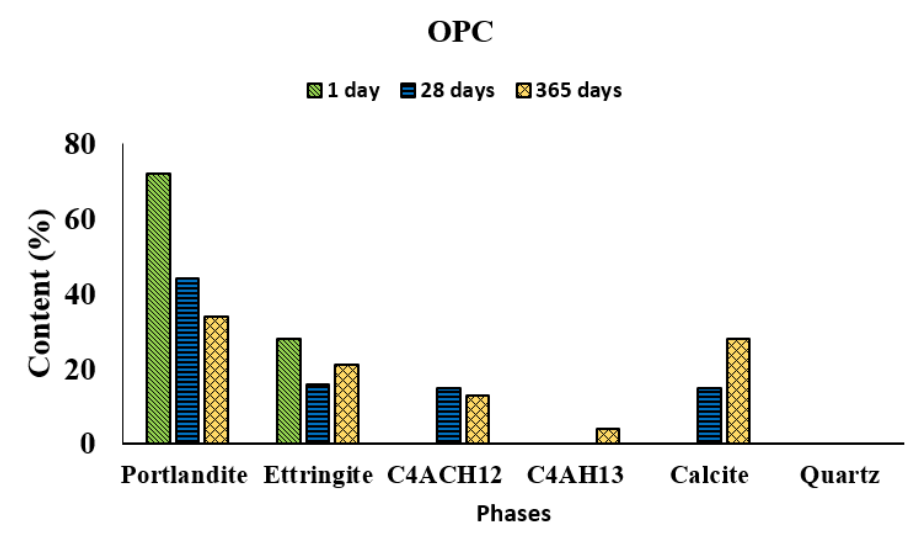

Figure 3. Mineral composition of OPC paste determined by XRD.

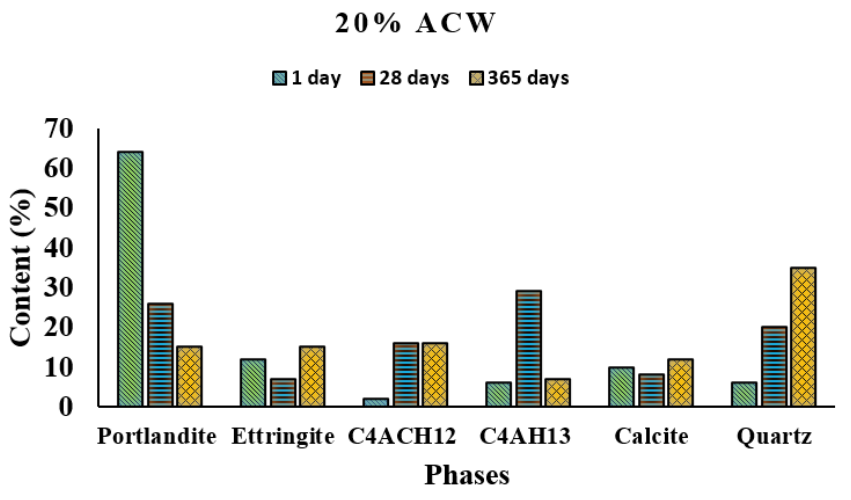

Figure 4. Mineral composition of $20 \%$ ACW determined by XRD.

As in OPC, portlandite was the majority phase in the 1 day $20 \%$ ACW. Quartz, absent in OPC, was detected in the blended cement. The pattern of variation with reaction time of ettringite, tetracalcium aluminate carbonate hydrate $\left(\mathrm{C}_{4} \mathrm{AcH}_{12}\right)$ and tetracalcium aluminate hydrate $\left(\mathrm{C}_{4} \mathrm{AH}_{13}\right)$ also differed in $20 \%$ AWC relative to OPC.

Ettringite was the second-most abundant phase in the latter paste only up to day 1 , when $\mathrm{C}_{4} \mathrm{AcH}_{12}$ and $\mathrm{C}_{4} \mathrm{AH}_{13}$ formation was clearly visible. The inclusion of $20 \% \mathrm{ACW}$ favored the formation of $\mathrm{C}_{4} \mathrm{AH}_{13}$, which was the majority phase at 28 days. Its appearance was attributed to the supersaturation of the aqueous phase with calcium hydroxide. The high concentrations of $\mathrm{Ca}^{2+}$ and $\mathrm{OH}^{-}$in the solution due to the presence of $\mathrm{Ca}(\mathrm{OH})_{2}$ favored the precipitation of $\mathrm{C}_{4} \mathrm{AH}_{13}$, although the content of this phase declined in the 365 days samples.

Calcium monocarboaluminate is normally detected immediately after hydration. The reaction between $\mathrm{C}_{3} \mathrm{~A}$ and $\mathrm{CaCO}_{3}$ is governed by a solid-state mechanism, while the presence of the latter modifies the initial swift hydration of the former as a result of the barrier quickly generated by the reaction product, calcium carboaluminate hydrate. As hydration progresses, hemicarboaluminate gradually converts into monocarboaluminate. That process was not observed in the present study, however, because the first analysis was conducted $24 \mathrm{~h}$ after the materials were mixed with water. Calcite content grew with time.

\subsubsection{SEM/EDX Analyses}

The combined use of these two techniques afforded information on the morphology, texture and chemical composition of the hydrated phases, and particularly about the phases that could not be identified with XRD. SEM identified C-S-H gels (Figure 5). In the first 365 days, their $\mathrm{CaO} / \mathrm{SiO}_{2}$ ratio ranged from 1.6 to 2.5 , therefore constituting Taylor classification type II gels. The ratio was closer to 2.5 in the OPC gels and lower in the gels present in the blended cement. Structural order 
rose with higher $\mathrm{Ca} / \mathrm{Si}$ moduli and longer reaction times. In the early age pastes (1 day), the $\mathrm{C}-\mathrm{S}-\mathrm{H}$ gels comprised flaky clusters (Figure $5 \mathrm{~B}$ ), whereas at later ages (28 days) they exhibited thin layers of $\mathrm{C}_{4} \mathrm{AcH}_{12}, \mathrm{C}_{4} \mathrm{AH}_{13}$ and portlandite intergrowths (Figure $5 \mathrm{~A}$ ). All three products were consistently laminar although their sizes varied. At longer hydration times (365 days), thin layers of portlandite aggregated into more compact clusters (Figure 5D), while ettringite prisms grew in the voids, together with C-S-H gel and thin layers of $\mathrm{C}_{4} \mathrm{AcH}_{12}$ and $\mathrm{C}_{4} \mathrm{AH}_{13}$.
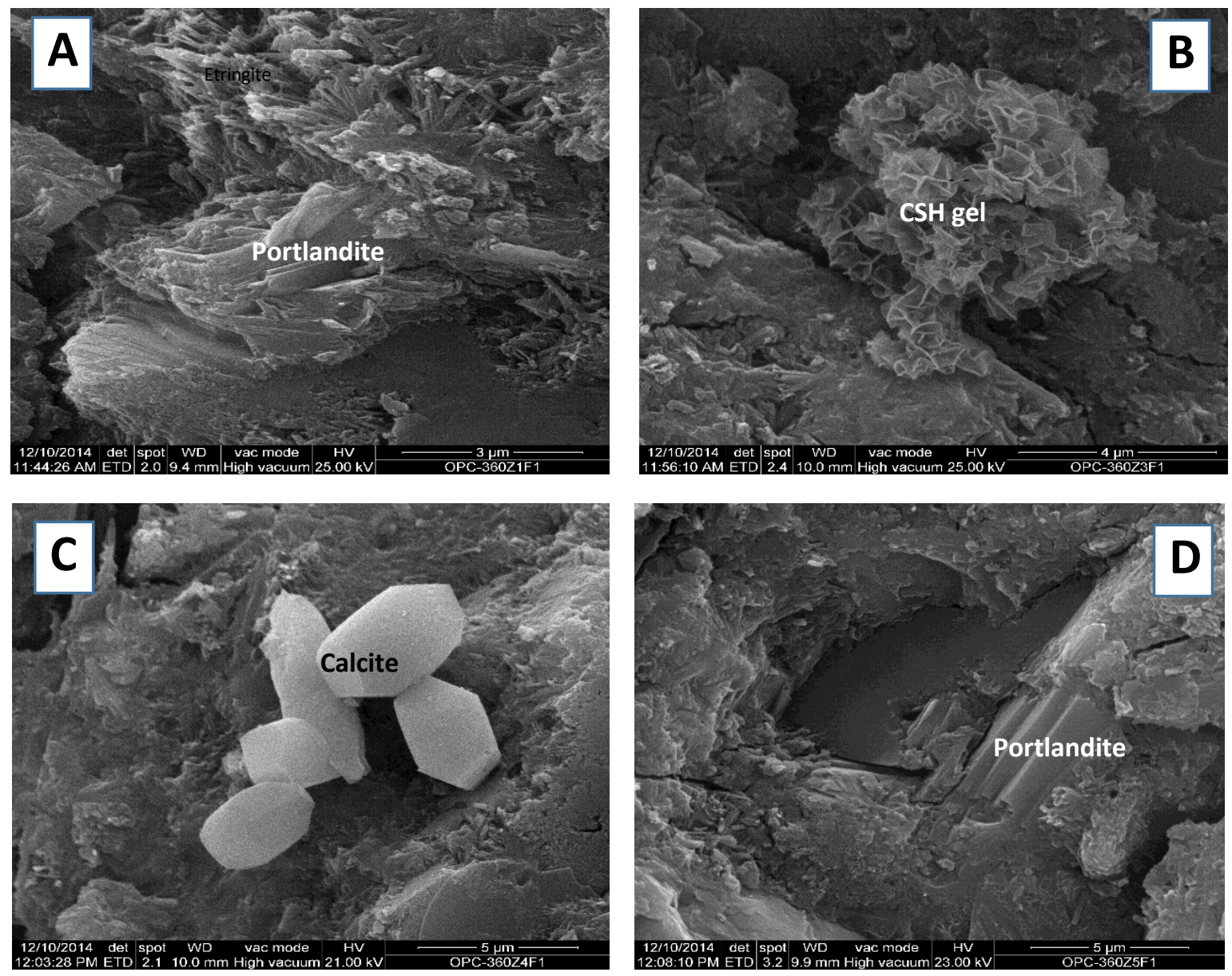

Figure 5. SEM micrographs of OPC and 20\% ACW cement pastes at different curing times:

(A) portlandite, (B) CSH gel, (C) calcite and (D) portlandite.

The inclusion of $20 \% \mathrm{ACW}$ induced a more compact microstructure in the blended cement cured at 365 days, which exhibited larger and thicker layers of $\mathrm{C}_{4} \mathrm{AH}_{13}$ and portlandite. Moreover, the $\mathrm{C}-\mathrm{S}-\mathrm{H}$ gel and prismatic ettringite clusters were less porous in the blended paste, in which rhombohedral calcite crystal content was likewise significant (Figure 5C).

\subsubsection{TG/DTA}

According to the thermal differential analyses (Figure 6), both cements exhibited three main endothermal signals. The wide band at $20^{\circ} \mathrm{C}$ to $200{ }^{\circ} \mathrm{C}$ was attributed to water loss $\left(45-50{ }^{\circ} \mathrm{C}\right)$; the band at $95{ }^{\circ} \mathrm{C}$ to $100{ }^{\circ} \mathrm{C}$ to ettringite and $\mathrm{C}-\mathrm{S}-\mathrm{H}$ gel dehydroxylation; and the band at $130{ }^{\circ} \mathrm{C}$ to $200{ }^{\circ} \mathrm{C}$ to the dehydroxylation of silicoaluminate $\left(\mathrm{C}_{2} \mathrm{ASH}_{8}\right)$ and tetracalcium aluminate $\left(\mathrm{C}_{4} \mathrm{AH}_{13}\right)$ hydrates, characteristically found in metakaolinite-based pozzolans [32,33]. Further to the XRD and SEM findings, the peak at $140{ }^{\circ} \mathrm{C}$ can be attributed primarily to $\mathrm{C}_{4} \mathrm{AH}_{13}$ formation. The content of this hydrated phase rose with reaction time, particularly where carbon waste was present in the cement 
paste. No losses were identified at temperatures of around $200^{\circ} \mathrm{C}$, which would be attributed to carbo-aluminate phase $\left(\mathrm{C}_{4} \mathrm{AcH}_{12}\right)$ decomposition.
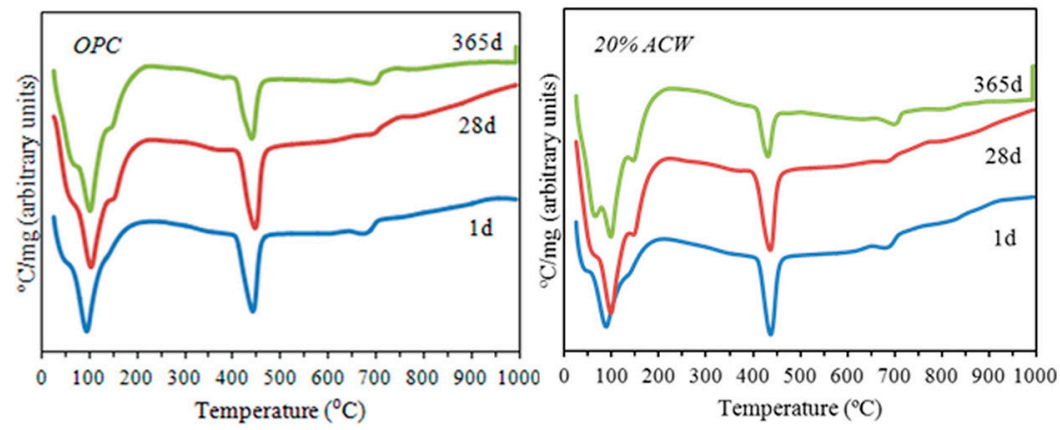

Figure 6. DTA curves for OPC and $20 \%$ ACW by hydration time.

Portlandite dehydroxylation was observed at $400{ }^{\circ} \mathrm{C}$ to $500^{\circ} \mathrm{C}$. The $\mathrm{Ca}(\mathrm{OH})_{2}$ contents from TG curves and the portlandite content (fixed lime: $100-(20 \%$ ACW/OPC $\times 100))$ in the pastes containing $20 \%$ ACW compared to OPC is given in Table 3 for the three reaction times studied.

Table 3. $\mathrm{Ca}(\mathrm{OH})_{2}$ contents (\%) and difference in both cements.

\begin{tabular}{cccc}
\hline Cements & 1 Day & 28 Days & 365 Days \\
\hline OPC & 13.7 & 17.9 & 19.4 \\
20\% ACW & 12.5 & 15.7 & 11.3 \\
Difference & -8.5 & -12.1 & -41.8 \\
\hline
\end{tabular}

Pursuant to these data, the ACW clearly exhibited pozzolanic activity after 28 days due to the pozzolanic reaction between the metakaolinite and the portlandite generated during portland cement hydration, with the formation, primarily, of additional amounts of $\mathrm{C}-\mathrm{S}-\mathrm{H}$ gels and $\mathrm{C}_{4} \mathrm{AH}_{13}$, as discussed earlier.

The endothermal band at $650{ }^{\circ} \mathrm{C}$ to $700{ }^{\circ} \mathrm{C}$ was attributed to decarboxylation of the calcite present in both the starting OPC and the partially carbonated samples (an effect of curing and storage).

\subsubsection{Micro-Raman}

The 365 days Raman spectra for the OPC and 20\% ACW pastes are shown in Figure 7. Both exhibited signals generated by characteristic cement hydration products: $\mathrm{C}-\mathrm{S}-\mathrm{H}$ gel $\left(668 \mathrm{~cm}^{-1}\right)$, ettringite and monosulfoaluminate $\left(999 \mathrm{~cm}^{-1}\right.$ to $\left.980 \mathrm{~cm}^{-1}\right)$. Whereas the signal peaking at $1084 \mathrm{~cm}^{-1}$ and assigned to calcite was narrow on the OPC spectrum, in the spectrum for the sample containing $20 \%$ waste it was wider $\left(1070-1050 \mathrm{~cm}^{-1}\right)$ due to the presence of carboaluminate-like compounds. The OPC paste spectrum also contained a signal attributable to the $\mathrm{OH}$ groups in unreacted portlandite.

The ${ }^{29} \mathrm{Si}$ NMR spectra for the 365 days samples recorded to determine the characteristics of the C-S-H gel formed are reproduced in Figure 8. The weak signal observed at $-71 \mathrm{ppm}$ indicated that, despite the time elapsing, both pastes contained anhydrous phases. The main difference between the two spectra was that the Q1 unit signal was much more intense in the OPC than in the $20 \%$ ACW cement paste, denoting a smaller proportion of end of chain units and hence a higher degree of polymerization in the latter. Other authors have reported similar results for the pozzolanic reaction in fired clay-based waste [34]. Furthermore, the amount, distribution and microstructural characteristics of the C-S-H gel formed have a significant effect on the mechanical strength of the cement. Studies conducted by Tobón et al. [35] showed that strength rises with the amount of C-S-H gel. The presence of over $5 \%$ pozzolanic materials (which generate more polymerized gels), in turn, raised blended cement compressive strength substantially. 


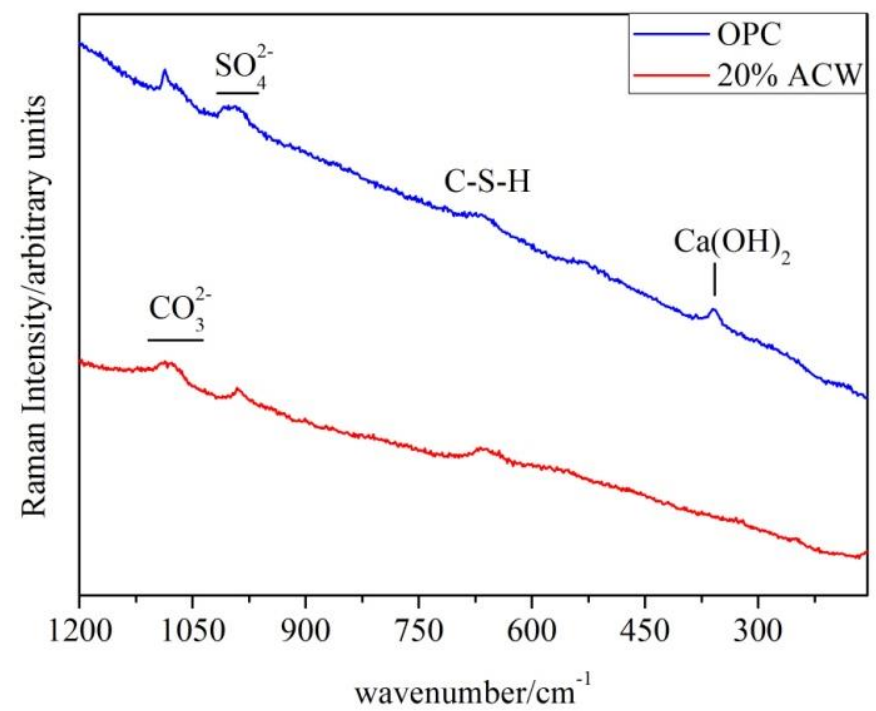

Figure 7. Micro-Raman spectra for 365 days OPC and 20\% ACW pastes.

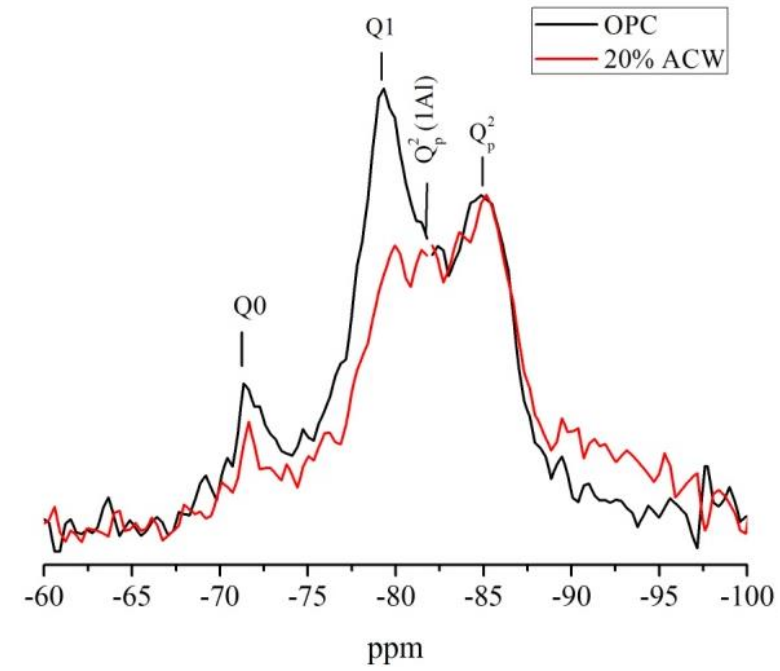

Figure 8. ${ }^{29} \mathrm{Si}$ NMR spectra for 365 days OPC and 20\% ACW pastes.

\section{Conclusions}

As a result of its kaolinitic nature, coal mining waste affords an alternative avenue for obtaining metakaolinite, with substantial environmental and social benefits, one of the main pillars of the European circular economy.

The optimal sintering temperature for thermally activating coal waste, $600{ }^{\circ} \mathrm{C}$, induces phyllosilicate dehydroxylation, giving rise to pozzolanic metakaolinite. When the temperature reaches $900{ }^{\circ} \mathrm{C}$, in contrast, spinel-like phases form, lowering pozzolanicity. The amorphism and porosity of the metakaolinite clusters formed afford the material a high pozzolanic index, comparable to the indices for other highly reactive pozzolans.

Further to the mineralogical, chemical and microstructural findings discussed above, ACW is apt for use as a pozzolanic material in blended cements. The addition of $20 \% \mathrm{ACW}$ to OPC intensifies $\mathrm{C}_{4} \mathrm{AcH}_{12}$ and $\mathrm{C}_{4} \mathrm{AH}_{13}$ formation. In the presence of the activated waste, $\mathrm{C}_{4} \mathrm{AH}_{13}$ is the majority reaction product. Its higher content induces more compact microstructures with a greater abundance 
of thin layers of $\mathrm{C}_{4} \mathrm{AH}_{13}$ and portlandite and lesser amounts of porous $\mathrm{C}-\mathrm{S}-\mathrm{H}$ gel and ettringite clusters. The $\mathrm{C}-\mathrm{S}-\mathrm{H}$ gel forming in OPC may exhibit fairly high $\mathrm{Ca} / \mathrm{Si}$ ratios.

Economically, energetically and mineralogically speaking, coal tailings are apt for manufacturing eco-efficient cements, for at $600{ }^{\circ} \mathrm{C}$ kaolinite is fully converted to metakaolinite, whose hydration generates the same amorphous and crystalline compounds as ordinary cement.

Acknowledgments: This research was funded by the Spanish Ministry of the Economy and Competitiveness under coordinated projects MAT2012-37005-CO3-01, BIA2015-65558-C3-1-2-3R (MINECO/FEDER).

Author Contributions: The first author and head researcher for this study, Moises Frías, planned the experiments, conducted the TG/DTA analyses and drafted the manuscript. Rosario García and Raquel Vigil helped plan the paper and conducted the XRD and SEM-EDX trials. Sagrario Martínez conducted the micro-Raman and NMR studies and revised the manuscript.

Conflicts of Interest: The authors declare no conflict of interest.

\section{References}

1. Environment. Available online: http://ec.europa.eu/environment/circular-economy/index_en.htm (accessed on 25 April 2016).

2. Cement: Compositions, Specifications and Conformity Criteria for Common Cements. Available online: http: //www.din.de/en/getting-involved/standards-committees/nabau/projects/wdc-proj:din21:204548497 (accessed on 17 March 2014).

3. Stark, J. Recent advances in the field of cement hydration and microstructure analysis. Cem. Concr. Res. 2011, 41, 666-678. [CrossRef]

4. Juenger, M.C.G.; Siddique, R. Recent advances in understanding the role of supplementary cementitious materials in concrete. Cem. Concr. Res. 2015, 78, 71-80. [CrossRef]

5. Soriano, L.; Monzó, J.; Bonilla, M.; Tashima, M.M.; Payá, J.; Borrachero, M.V. Effect of pozzolans on the hydration process pof portland cement cured at low temperatures. Cem. Concr. Compos. 2013, 42, 41-48. [CrossRef]

6. Nezerka, V.; Slízková, Z.; Tesárek, P.; Plachý, T.; Franeová, D.; Petráñová, V. Comprehensive study on mechanical properties of lime based pastes with additions of MK and brick dust. Cem. Concr. Res. 2014, 64, 17-29. [CrossRef]

7. Pavlík, V.; Uzáková, M. Effect of curing conditions on the properties of lime, lime-MK and lime-zeolite mortars. Constr. Build. Mater. 2016, 9, 14-25. [CrossRef]

8. Cassagnabere, F.; Escadeillas, G.; Mouret, M. Study of the reactivity of cement/MK binders at early age for specific use in steam cured precast concrete. Constr. Build. Mater. 2009, 23, 775-784. [CrossRef]

9. Frías, M. The effect of MK on the reaction products and microporosity in blended cement pastes submitted to long hydration time and curing temperature. Adv. Cem. Res. 2006, 18, 1-6. [CrossRef]

10. Frías, M. Study of hydrated phases present in a MK-lime system cured at $60^{\circ} \mathrm{C}$ and 60 months of reaction. Cem. Concr. Res. 2006, 36, 827-831. [CrossRef]

11. Martínez, S.; Frías, M. Micro-raman study of stable and metastable phases in $\mathrm{MK} / \mathrm{Ca}(\mathrm{OH})_{2}$ system cured at $60^{\circ} \mathrm{C}$. Appl. Clay Sci. 2011, 51, 283-286. [CrossRef]

12. Frías, M.; García, R.; Vigil, R.; Ferreiro, S. Calcination of art paper sludge waste for the use as a supplementary cementing material. Appl. Clay Sci. 2008, 42, 189-193. [CrossRef]

13. Rodríguez, O.; Frías, M.; de Rojas, M.I.S. Influence of the calcined paper sludge on the development hydration heat in blended cement mortars. J. Therm. Anal. Calorim. 2008, 92, 865-871. [CrossRef]

14. Frías, M.; Vigil, R.; García, R.; de Rojas, M.I.S.; Baloa, T. Mineralogical evolution of MK-based drinking water treatment waste for use as pozzolanic material. The effect of activation temperature. J. Am. Ceram. Soc. 2013, 96, 3188-3195.

15. Prasad, S.; Byragi, T.; Vadde, R. Environmental aspects and impacts its mitigation measures of corporation coal mining. Procedia Earth Planet. Sci. 2015, 11, $2-7$.

16. Zhang, Y.; Ge, X.; Nakano, J.; Liu, L.; Wang, X. Pyrite transformation and sulfur dioxide release during calcination of coal gangue. RSC Adv. 2014, 4, 42506-42513. [CrossRef]

17. Bian, Z.; Dong, J.; Lei, S.; Leng, H.; Mu, S.; Wang, H. The impact of disposal and treatment of coal mining wastes on environment and farmland. Environ. Geol. 2009, 58, 625-634. [CrossRef] 
18. Liu, H.; Liu, Z. Recycling utilization patterns of coal mining waste in China. Resour. Conserv. Recycl. 2010, 54, 1331-1340. [CrossRef]

19. Beltramini, L.; Suarez, M.; Guillarducci, A.; Carrasco, M.; Grether, R. Aprovechamiento de residuos de la depuración del carbón mineral: Obtención de adiciones puzolánicas para el cemento Portland. Tecnol. Cienc. 2010, N.4, 7-18.

20. Li, D.; Song, X.; Gong, C.; Pan, Z. Research on cementitious behaviour and mechanism of pozzolanic cement with coal gangue. Cem. Concr. Res. 2006, 36, 1752-1759. [CrossRef]

21. Zhang, T.; Gao, P.; Gao, P.; Wei, J.; Yu, Q. Effectiveness of novel and traditional methods to incorporate industrial wastes in cementitious materials-An overview. Resour. Conserv. Recycl. 2013, 74, 134-143. [CrossRef]

22. Frías, M.; Vigil, R.; de Rojas, M.I.S.; Medina, C.; Valdés, J. Scientific aspects of kaolinite based coal mining wastes in pozzolan $/ \mathrm{Ca}(\mathrm{OH})_{2}$ system. J. Am. Ceram. Soc. 2012, 95, 386-391. [CrossRef]

23. Frías, M.; de Rojas, M.I.S.; García, R.; Valdés, J.; Medina, C. Effect of activated coal mining wastes on the properties of blended cement. Cem. Concr. Compos. 2012, 34, 678-683. [CrossRef]

24. García, R.; Vigil, R.; Frías, M.; Rodriguez, O.; Martínez, S.; Fernández, L.; de Soto, I.S.; Villar, E. Mineralogical study of calcined coal waste in a pozzolan $/ \mathrm{Ca}(\mathrm{OH})_{2}$ system. Appl. Clay Sci. 2015, 108, 45-54. [CrossRef]

25. Vegas, I.; Cano, M.; Arribas, I.; Frías, M.; Rodríguez, O. Physical-mechanical behaviour of binary cements blended with thermally activated coal mining waste. Constr. Build. Mater. 2015, 99, 169-174. [CrossRef]

26. AENOR. Spanish Standard UNE 80 304: 2006; Cements. Calculations of potential composition of Portland Clinker; AENOR: Madrid, Spain, 2006.

27. Ambroise, J.; Murat, M.; Pera, J. Investigations on synthetic binders obtained by middle-temperature thermal dissociation of clay minerals. Silic. Ind. 1986, 7, 99-107.

28. Sayanam, R.A.; Kalsotra, A.K.; Mehta, S.K.; Singh, R.S.; Mandal, G. Studies on thermal transformations and pozzolanic activities of clay from Jammu region (India). J. Therm. Anal. 1989, 35, 99-106. [CrossRef]

29. Villar, E.; Valencia, E.; Santos, S.F.; Savastano, H.; Frías, M. Pozozlanic behaviour of bamboo leaf ash: Characterization and determination of the kinetic paprameters. Cem. Concr. Compos. 2011, 33, 68-73. [CrossRef]

30. De Sánchez Rojas, M.I.; Rivera, J.; Frías, M. Influence of the microsilica state on pozzolanic rate. Cem. Concr. Res. 1999, 29, 945-949. [CrossRef]

31. Hewllet, P.C. Lea's Chemistry of Cement and Concretes, 4th ed.; Arnold: London, UK, 1998.

32. Frías, M.; Rodríguez, O.; de Rojas, M.I.S. Paper sludge, an environmentally sound alternative source of MK based cementitious materials. A review. Constr. Build. Mater. 2015, 74, 37-48. [CrossRef]

33. Frías, M.; Martínez, S.; Blasco, T.; Frías-Rodríguez, M. Evolution of mineralogical phases by ${ }^{27} \mathrm{Al}$ and ${ }^{29} \mathrm{Si}$ $\mathrm{NMR}$ in MK-Ca(OH)$)_{2}$ system cured at $60^{\circ} \mathrm{C}$. J. Am. Ceram. Soc. 2013, 96, 2306-2310. [CrossRef]

34. Medina, C.; del Bosque, I.F.S.; Asensio, E.; Frías, M.; de Sanchez Rojas, M.I. Mineralogy and microstructure of hydrated phases during the pozzolanic reaction in the sanitary ware waste $/ \mathrm{Ca}(\mathrm{OH})_{2}$ system. J. Am. Ceram. Soc. 2016, 99, 340-348. [CrossRef]

35. Tobón, J.I.; Payá, J.J.; Borrachero, M.V.; Restrepo, O.J. Mineralogical evolution of Portland cement blended with silica nanoparticles and its effect on mechanical strength. Constr. Build. Mater. 2012, 36, 736-742. [CrossRef]

(C) 2016 by the authors; licensee MDPI, Basel, Switzerland. This article is an open access article distributed under the terms and conditions of the Creative Commons Attribution (CC-BY) license (http://creativecommons.org/licenses/by/4.0/). 